\title{
A FUTURE PERSPECTIVE ABOUT TOURISM AND POWER: A POLYPHONIC DIALOGUE IN THE AGORA
}

\author{
ERDIN AKMAK AND RAMI K. ISAAC \\ Academy for Tourism, NHTV Breda University of Applied Sciences, Breda, The Netherlands
}

In our introduction to this issue we provide a chronological discussion of science and power relations in academia and set the scene for the articles featured in this special issue. This endnote works to a reverse formula, looking forward and seeking if not to unweave the dominating discourse of centrality in the tourism academia and pointing out for further advancing the often complex discussions by different traditions of academia.

On the top of that, the articles in this special issue by no means capture the full array of interesting studies being conducted in the area of science and power relations in tourism studies. Obviously, research and discussions related to some of the bigger and relevant trends in recent years (e.g., gender and tourism academy, tokenism, diversity including age, class, ethnicity, national origin, religion, and even disciplinary) do not appear in this issue. This is not to suggest that they do not contribute to this area or are not important. Rather, the included articles simply represent a small sampling of the stimulating issues that research on science and power relations is taking. We hope that this special issue serves to inspire tourism scholars to expand their efforts to examine how science and power relations might shed light on the impacts of their life worlds as academics, on the processes of their cultural consumption, and affect in ways that continue to be methodologically rigorous and practically meaningful. We do hope also that future conference organizers, as the moderators of the "agora” (Arendt, 1958), will strive for giving an equal space to different traditions-from whatever perspectives they are-and balancing the power in on-going discussions in the tourism academia.

Despite the informal suggestions made by keynote speakers and panelists in tourism conferences and as well as by discussants in online forums (e.g., TRINET and Atlas) for opening up the academy, undoing the hierarchy, and balancing the power, the paradigm shift of decentring academia moves very slowly, almost negligible. This is exactly in line with the deconstruction of dominating discourse. We always see the same people delivering the keynotes in tourism conferences and framing on-going discussions in academia. To make significant advances in this area, we call for further efforts to decenter contemporary tourism academia by including other voices, particularly the "silent or (silenced) voices" to consider the new and challenging thinking by "the unspoken." Although there is no single agreed upon definition of "silent voices," one can nevertheless specify generally agreed elements of diversity such as age, gender, ethnic origin, social, and ability. According to Swadener and Mutua (2008), decolonization project involves the "valuing, reclaiming, and foregrounding of indigenous voices and epistemologies” (p. 31). Effective 
diversity in these elements can help to break these barriers to acceptance of silent/silenced voices in the tourism academia.

Secondly, we think that different traditions meet together in the agora without dominating one to another. The importance of decolonizing research is placed on "forging cross-cultural partnerships, with, between, and among indigenous researchers, scholars and allied others" (Rogers \& Swadener, 1999, p. 31). The explanatory power of Kuhn's "gestalt switch" might be very helpful when considering an opposing view of a tradition, which represents a side in the discussion in the agora. This means a discussant's mind needs to switch from its own to the other to see the other and to achieve a renewed mind. This space, agora, similarly to the public sphere as Habermas (1981/1984) suggested, needs to be designed as where individuals and groups from different traditions could express their needs and interests. In their discussions and evaluations of contemporary issues, they could oppose the formal state and market powers, and dominant powerful groups in the tourism academia with a purpose of helping to shape public opinion.

Undoubtedly, another acute problem of tourism academia is the lingua franca. English with its hegemonic position dominates the communication and publication language in academia. It is marketed as the prestigious brand of the language (Buripakdi, 2014) around the world. Because every hegemonic construct is concerned with standardization, the standard English is refined with being rational, moral, civilized, and intelligent whereas the nonstandard one is seen as irrational, emotional, materialist, and imprudent (Joseph, 1987). This standardization and unequal power relations may result in the Bourdieu's (1991) notion of symbolic violence. Bourdieu (1991) contends that symbolic violence takes place "when individuals mistakenly consider a standard dialect or style of speaking to be truly superior to the way they themselves speak, rather than an arbitrary difference afforded social significance” (p. 170). Besides that, Said (1994) suggests, "the level of a technical language stripped of expressive and aesthetic characteristics and denuded of any critical or selfconscious dimension" (p. 369). In effect, communicating and publishing in English does not just mean learning or using a foreign language but "unconscious implantation of the Anglocentric attitudes or the perspective of the dominant race in the native's mind” (Tripasai, 2004, p. 11). Pennycook (1994) argues that the underlying goal of the promotion of global English is to protect and promote capitalist interests and subsequently the (neo)colonial ideology remains even stronger today. This positioning is mistaken and unhealthy in representing different traditions equally in tourism academia. As Rushdie (1982) claims, "the language needs to be decolonized, to be made in other images, if those of us who use it from positions outside Anglo-Saxon cultures are to be more than 'Uncle Toms'” (p. 8). Standard English discourse privileges only those who have access to its possession while leaving others marginalized (Bhatt, 2001). Accordingly, there is a need to differentiate the working language in academia where native languages enrich discussion in the agora with their symbolic value and literature. Through decentering the Anglo-Saxon core position, the dominating Western discourse might be changed into a polyphonic (Clifford, 1988) and including one that values the excluded voices of our global village.

\section{References}

Arendt, H. (1958). The human condition. Chicago, IL: The University of Chicago Press.

Bhatt, R. M. (2001). Language economy, standardization, and World Englishes. In E. Thumboo (Ed.), The three circles of English: Language specialists talk about the English language (pp. 401-422). Singapore: UniPress.

Bourdieu, P. (1991). Language and symbolic power. Oxford, UK: Polity Press.

Buripakdi, A. (2014). Hegemonic English, standard Thai, and narratives of the subaltern in Thailand. In P. Liamputtong (Ed.), Contemporary socio-cultural and political perspectives in Thailand (pp. 95-110). The Netherlands: Springer.

Clifford, J. (1988). The predicament of culture: Twentiethcentury ethnography, literature, and art. Cambridge, MA: Harvard University Press.

Habermas, J. (1984). Reason and the rationalization of society. Volume 1 of The theory of communicative action (T. McCarthy, Trans.). Boston, MA: Beacon Press. (Original work published in German in 1981).

Joseph, J. E. (1987). Eloquence and power: The rise of language standards and standard languages. London: Pinter.

Pennycook, A. (1994). The cultural politics of English as an international language. Essex, UK: Longman. 
Rogers, L. J., \& Swadener, B. B. (1999). Reflections on the future work on anthropology and education: Reframing the field. Anthropology and Education, 30, 436-440.

Rushdie, S. (1982). The Empire writes back with a vengeance. Times, 3, p. 8.

Said, E. W. (1994). Culture and imperialism. London: Vintage.

Swadener, B. B., \& Mutua, K. (2008). Decolonizing performances: Deconstructing the global postcolonial.
In N. K. Denzin, Y. S. Lincoln, \& L. T. Smith (Eds.), Handbook of critical indigenous methodologies (pp. 3143). Thousand Oaks, CA: Sage.

Tripasai, P. (2004). Debating Anna: The textual politics of English literature teaching in Thailand. Retrieved from http://www.aare.edu.au/publications-database.php/4518/ debating-anna-the-textual-politics-of-english-literatureteaching-in-thailand 